\title{
Shembe, the Black Messiah: A Postcolonial Intervention
}

\author{
Magnus Echtler
}

To the late Zakhona Maduna-I hope you dance in heaven

\begin{abstract}
Der akademische Diskurs über die Nazareth Baptist Church, Südafrika, kreist um die theologische Frage nach dem messianischen Charakter des Kirchengründers und seiner Nachfolger. Frühe Interpretationen schlossen die Kirche aus der Christenheit aus, während spätere, zum Teil explizit postkoloniale Analysen für ihre Inklusion plädierten. Allerdings üben beide Klassifizierungen, Exkommunizierung wie Kanonisierung, epistemische Gewalt aus, und das Argument für den christlichen Charakter der Kirche erfordert es, Stimmen der Laien zum Schweigen zu bringen. Aus meiner sozialanthropologischen Perspektive bestehe ich auf der zentralen Bedeutung der Standpunkte gewöhnlicher Kirchenmitglieder, und betone die messianischen Traditionen der Kirche in meinem Beitrag. Da man der theologischen Rahmung nicht entkommen kann, argumentiere ich, dass die einzige Möglichkeit, diese Stimmen im akademischen Diskurs zu Gehör zu bringen, darin besteht, der Kennzeichnung „schwarzer Messias“ als (Re-)Präsentation für Shembe Geltung zu verschaffen.
\end{abstract}

\section{Introduction $^{1}$}

In his book on the early history of the Nazareth Baptist Church (NBC) in South Africa, Andreas Heuser argued that the church's founder, Isaiah Shembe, refused the label of Black Messiah. And added, as an aside in a footnote, that "the

1 I thank the Nazarites of eBuhleni for making research with them such a pleasurable experience, the DFG for the financial support, and Christian Wetz for the invitation to take part in postcolonial discourse and for sharing his theological expertise.

(C) MAGNUS ECHTLER, 2020 | DOI:10.1163/9789004417434_010

This is an open access chapter distributed under the terms of the CC BY-NC 4.o license.us Echt ler - 9789004417434 
idea of a usurpation of Christ through Shembe is rooted in parts of the present day membership and expressed publicly in the slogan 'Shembe is the way"'2. This seems to be rather typical of the dominant position in recent academic discourse on the NBC, which focuses on Isaiah and his time, and combines the emphasis on the Christian character of the church with a disregard of the views of the laity. This misrepresentation calls for an intervention; therefore, I present Shembe as the Black Messiah here.

My intervention is based on my academic position. As a trained anthropologist, I have conducted ethnographic research since 2008, producing contemporary data on the NBC's majority branch, based at eBuhleni, under the leadership of Vimbeni and Mduduzi Shembe. My theoretical frame, Bourdieu's practice theory primarily, favors the views of the laity, as the followers produce the leader's standing or symbolic capital. ${ }^{3}$ But my intervention also draws upon postcolonial considerations. Drawing upon Karl Marx, Gayatri Spivak emphasized how the two senses of representation, representation as Darstellung and Vertretung, play together, namely, that "the staging of the world in representation [...] dissimulates the choice of and need for 'heroes', paternal proxies, agents of power"4. Shembe-and I mean Isaiah and his successors as represented in the idea of the eternal, spiritual Shembe or the Black Messiah - was such a hero, and through him "a point of crystallization has been reached for a large section of the Zulu people"5. Shembe represents these people, his followers. But how do we re-present him? As madman, revolutionary, prophet, bishop, lord, or Black Messiah? I have a problem with the academic discourse on the NBC if it downplays or outright silences the ways in which the church members re-present their leader. Of course, historical studies need not take account of later developments. But if the discourse is dominated by studies of the NBC's early history that insist on its Christian character, it exerts epistemic pressure. What does it mean when present day members claim that "Shembe

2 Andreas Heuser, Shembe, Gandhi und die Soldaten Gottes: Wurzeln der Gewaltfreiheit in Südafrika, Religion and Society in Transition 4, Münster etc. 2003, 21 n27. My translation.

3 Cf. Magnus Echtler, Shembe is the Way: The Nazareth Baptist Church in the Religious Field and in Academic Discourse, in: Magnus Echtler/Asonzen Ukah (eds.), Bourdieu in Africa: Exploring the Dynamics of Religious Fields, SRA 44, Leiden 2016, 236-266, here 238-239.260-261.

4 Gayatri Chakravorty Spivak, Can the Subaltern Speak?, in: Patrick Williams/ Laura Chrisman (eds.), Colonial Discourse and Post-Colonial Theory, New York 1993, 66111, here 74 .

5 Gerhardus Cornelius Oosthuizen, The Theology of Londa Shembe and the amaNazaretha of EKuphaKameni, in: Irving Hexham (ed.) The Scriptures of the amaNazaretha of Ekuphkameni: Selected Writings of the Zulu Prophets Isaiah and Londa Shembe, Calgary 1994, xxiii-xlix, here xlviii. 
is the way"? Have they misunderstood something? Have they betrayed the founder's ideas? Or have they freed themselves from colonial shackles? By representing Shembe as the Black Messiah, a line of tradition that is not too hard to unearth in the history of the NBC, I wish to elaborate insurgency "as a counter possibility for the narrative sanctions granted to the colonial subject" 6 in academic discourse.

That the members' views have not played a larger role in academic discourse is especially striking since the Nazareth Baptist Church is unique among African Independent Churches with regard to the amount of oral traditions available. The church's founder Isaiah, as well as his successors Johannes and Amos, collected members' accounts of their miraculous deeds, sermons and other events, and compiled them into the "Acts of the Nazarites", which have been published from the 1990s onward. These accounts provide evidence for the members' representation of their leaders, but they are multi-vocal and offer divergent representations, and can thus support conflicting interpretations. Allan Anderson, for example, argued that "[i]nstead of being a 'Messiah' or 'Black Christ', Isaiah Shembe is the 'servant of the lord', 'the man sent by God' who is obedient to the bidding of God" 7 in most of the oral traditions of the church. While I do not contest that all these representations can be found in the oral traditions, I argue here that the representation of Shembe as Black Messiah has a strong tradition in the NBC that should not be dismissed easily.

I interpret members' testimonies not as texts, but as hybrid performances in Homi Bhabha's sense, who argued that cultural meaning is not fixed but continuously created in the act of enunciation, and thus dependent on the positionality of the subject of enunciation "within the schemata and strategies of discourse" ${ }^{\text {. }}$. Representations of Shembe are not simply reproduced, but "appropriated, translated, re-historicized, and read anew" with "reference to a present time and a specific space" ${ }^{\prime 9}$ of the Nazarite testifying. The positionality of the speaker is relational, and one of the discursive conventions of the genre of miracle stories in the NBC is that Shembe is the spiritual agent, and the witness the patient. Thereby, miracle stories specify the relation between church member and leader, charge church doctrine with emotion, and reproduce Shembe's standing, his charismatic authority. ${ }^{10}$ The difference between

\footnotetext{
6 SPIVAK, Subaltern, 82.

7 Allan Anderson, Zion and Pentecost: The Spirituality and Experience of Pentecostal and Zionist/Apostolic Churches in South Africa, Pretoria 2000, 226.

8 Номі К. Внавна, The Location of Culture, London 2004, 53.

9 Op.cit., 55 .

10 Cf. Magnus Echtler, A Real Mass Worship They Will Never Forget: Rituals and Cognition in the Nazareth Baptist Church, South Africa, in: Angelos Chaniotis
} 
miracle stories representing Shembe as Servant of God or Black Messiah does hardly affect the relations between leader and followers, but fundamentally alters the church's relation to other Christian players in the field, from continuity to fundamental opposition. My interpretation of the testimonies is rather similar to the interpretation of the use of the Bible in the NBC proposed by Gerald West and Nkosinathi Sithole, but it extends to other religious practices. ${ }^{11}$

Practices mark and make a difference in the history of the NBC. In the first section of the chapter, I argue that the success of Isaiah Shembe rested on his charismatic authority, his ability to make a difference in the religious field. He offered radical alternatives, like dancing in African attire or Sabbath worship, and he performed miracles like those of the biblical Jesus. When Isaiah died, his successors routinized charisma as hereditary, and supported their position by traditional authority, a process that Isaiah had already started.

In the second section, I review the academic discourse on the NBC, in which the question of the Black Messiah has been the major theological controversy. My position is not new, but an updated social science version of classic approaches, especially that of Gerhardus Oosthuizen, and it agrees with, and elaborates upon the position taken by Sithole, himself a member of the church, in his recent monography. ${ }^{12}$ Academic discourse moves in waves or circles; the need to distinguish one's own position from those of other players is a driving force in the game, and pertains to the emphasis on history, textuality, and Christianity, as well as to my critique thereof.

In the last section, I discuss the iconography of the NBC, which offers representations of Shembe ranging from the servant of Christ to the eternal Shembe and the assertion that Shembe, rather than Jesus, is the way. In conclusion, I link the representation of Shembe with the question of what it means to be a member of the NBC today.

ET AL. (eds.), Body, Performance, Agency, and Experience, Ritual Dynamics and the Science of Ritual 2, Wiesbaden 2010, 371-397, here 381-384.

11 Cf. Gerald O. West, Reading Shembe 'Re-Membering' the Bible: Isaiah Shembe's Instructions on Adultery, in: Neotest. 40 (2006), 157-184; Nкosinathi Sithole, An African Bible for African Readers: J.G. Shembe's Use of the Bible in the Sermon, in: отE 24 (2011), 208-220.

12 Nkosinathi Sithole, Isaiah Shembe's Hymns and the Sacred Dance in Ibandla LamaNazaretha, SRA 45, Leiden 2016, 48-55. 
Isaiah Shembe was born around 1870 . As a child he had to flee from Natal to the Orange Free State, because his descent group, the Hlubi, was prosecuted for rebellion. As the main heir of one of the chief's counselors, Isaiah Shembe grew up to good standing, and headed a household with three wives in his late 20s, before the Anglo-Boer war (1899-1902) disrupted his life. ${ }^{13}$ According to Shembe's own accounts, voices and visions had called him to do God's work since childhood. Finally, he heeded the call and left his wives and family to become a travelling preacher and faith healer. ${ }^{14}$ Shembe was baptized by Saul Luphuthi, a Wesleyan teacher in Harrismith, and then, in 1906, a second time by William Matebule Lashega, leader of the African National Baptist Church, marking the transition from mission Christianity towards the nascent African Independency. ${ }^{15}$ In 1908 , Shembe moved from Harrismith to Natal and its urban center, Durban. His accounts emphasize his success as healer and preacher, producing large numbers of converts, who he handed over, rather indiscriminately, to Baptist, Wesleyan, or American Mission Board congregations. ${ }^{16}$ Isaiah Shembe founded his own church, the iBandla lamaNazaretha, or Nazareth Baptist Church in 1910.

\subsection{Producing Charisma and Distinction}

From the sociological point of view, Isaiah Shembe was a prophet, whose authority rested on his charisma, an extraordinary, originally magical or miraculous personal quality that has to prove and manifest itself continuously in the faith and devotion of the adherents. ${ }^{17}$ Isaiah Shembe himself considered his skill as healer and orator as foundational for his success, and Bengt Sundkler considered him a prime example of what he calls the prophet type of leadership in African Zionist Churches, based upon the leaders' ability to heal in

\footnotetext{
13 HEUSE R, Soldaten, 148-150.

14 Robert Papini, Carl Faye's transcript of Isaiah Shembe's testimony of his early life and calling, in: JRA 29 (1999), 243-284; John L. Dube, UShembe, Pietermaritzburg 1936, English translation M. YengwA, London University soAs, Manuscript No. 380082.

15 Esther Roberts, Shembe: The Man and his Works, Johannesburg 1936 (University of the Witwatersrand, MA Thesis), 28-29. In a 1990 sermon, Evangelist Ndelu of the NBC told a different version, in which the hand of the Wesleyan missionary was stayed three times when trying to baptize Shembe. Robert Papini, Rise Up and Dance and Praise God, Durban 1992, 24-25.

16 Dube, UShembe, 30; Papini, Shembe's testimony, 277; Roberts, Shembe, 29-30.

17 MaX WEBER, Wirtschaft und Gesellschaft: Grundriss der verstehenden Soziologie, Tübingen 1972, 140.268-269.654-656.
} 
continuity with the healer/diviner (isangoma) of Zulu religion. ${ }^{18}$ But apparently the scope of his charisma astonished. John Dube proposed that "even Kings and Princes from the royalty were not revered and respected in the same manner as Shembe was revered by the members of the Nazareth Church"19, and Sundkler suggested that "[t]here is probably no Zulu in modern times who has had such an intense influence over such a large number of people as Shembe"20. Ester Roberts characterized Shembe as "an enigma", whose "charming smile" and "soft and beautifully modulated voice contributed to his charm", yet who "had the poise of a person accustomed to obedience", and "liked to show his authority by keeping important chiefs waiting for days". She argued that " $[\mathrm{h}]$ is success was due to the combination of the imagination of a dreamer with the energy and directness of a man of action", and that "in Shembe's case there do not appear to have been outside causes which paved the way for his success" 21 .

For sociologists, however, social factors are decisive. To understand the success of prophets, argues Pierre Bourdieu, it is necessary to relate them to their followers and explain "why a particular individual finds himself socially predisposed to live out and express [...] ethical or political dispositions that are already present in a latent state amongst [...] his addressees" 22 . In order to challenge the legitimacy of established players in the field, missionaries or African diviners, for example, prophets need to mobilize deviant interests and latent dispositions, and therefore they often thrive in times of crisis, when the dissatisfied laity favors newcomers. Blacks in Natal and the surrounding areas started to convert to Christianity in numbers with the beginning of the 2oth century only, but by the 1920 , there were already plenty of black prophets claiming leadership of their own churches. ${ }^{23}$ The crisis that made the newcomers attractive - and that includes the white missionaries - was the gradual destruction of the precolonial African societies. Isaiah Shembe experienced this process personally, when his family had to flee after the colonial state destroyed the Hlubi as a coherent unit of social organization, and when the Anglo-Boer war violently restructured the whole of South Africa.

\footnotetext{
18 Bengt Sund kler, Bantu Prophets in South Africa, London 1961, 109.

19 Dube, UShembe, 98.

20 Sundkle R, Bantu Prophets, 110.

21 Roвerts, Shembe, 37-38.

22 Pierre Bourdieu, Legitimation and structured interest in Weber's sociology of religion, in: Scott LASh/SAm Whimster (eds.), Max Weber, Rationality and Modernity, London 1987, 119-136, here 130-131.

23 Heuse R, Soldaten, 150-151.
} 
The destruction of precolonial societies produced a new religious interest in the laity, namely a justification of their status as colonized, an interest that favored the new players in the religious field. Mission Christianity explained and excused colonialism as the prerequisite for the salvation of African souls as well as the way to civilization and modernity. Through Mission education emerged a westernized African bourgeoisie, who started to criticize the subservient position of Africans in Mission Churches, and, partly inspired by Afro-American churchmen, founded the first African Independent Churches from the 189os onward. While Africans led these new institutions, they did not fundamentally challenge the doctrine of Mission Christianity, and they regarded African customs as obstacles in the way to become modern Christians. By the 1920s, however, even the intellectuals began to reconsider the rejection of African traditions. A prominent representative of this development was John Langilebele Dube, first president of the South African Native National Congress and founder of the newspaper "Ilanga lase Natal", who not only wrote Shembe's biography, but also the first Zulu novel and a book giving advise on how to reconcile African customs with modern life-style. By that time, the second wave of African independency, the so-called Zionist Churches, had already repositioned themselves with regard to precolonial religious traditions in practice. Their elaborate rituals of healing deviated from Mission orthopractice, but agreed with the dispositions of that section of the laity, who expected religion to deal with problems in this life, and not just secure the salvation of the soul in afterlife.

That Isaiah Shembe acted as a Christian healer contributed to his charisma, but he shared this position in the religious field with many other Zionist leaders. Why was he exceptionally successful? Joel Cabrita argued that "Isaiah was unique in his ambitious and dramatic attempt to align his actions with the miracle-working Christ of the New Testament"24. His messianic habitus certainly played a role, and I will discuss it below. However, it is not clear to me how this would have made him particularly attractive to the section of the laity that proved to be decisive for the growth of his church, namely the uneducated Africans of rural Natal and Zululand, who had not yet converted to Christianity. The devotional literature of the NBC suggests a different answer.

The "Book of the Birth of the Prophet Shembe", a pamphlet that started to circulate in the NBC in the 1970s, presented a modified and extended version of

24 Joel Cabrita, Text and Authority in the South African Nazaretha Church, Cambridge 2014, 159 . 
Dube's "UShembe". 25 In the narrative, Isaiah Shembe became a successful healer when the white minister of a Wesleyan church asked him to lead the service. As he started "singing, a powerful spirit came: people threw up their sickness and bewitchment, which amazed everyone in the church that day", a transformation Shembe commented, "Indeed the Spirit of the Lord was upon me after that" ${ }^{26}$. Prompted by a dream, he read Mark 16:17-18, and thereafter "[a]ll those on whom Shembe laid hands in the name of the Lord were healed. That amazed everyone in the area, as there had never been anyone healed by prayer in all that place, and they wondered that he who healed by prayer was no mission Christian: he wore a fur girdle"27. Shembe as the agent of rupture, the bringer of Christian healing, was African, not Europeanized by mission education.

Later in the narrative, Isaiah Shembe returned to Natal because the congregation of the late prophet Mfazwe called for his help. This prophet had announced Shembe as the one "who is greater than me is coming, you will recognize him by the sound of the dance; he will be followed by people girded with traditional attire, carrying shields and with plumes of the black finch on their heads; he shall not exclude; all shall follow him"28. Johnson Benjamin Mfazwe, who died in 1903, had been the most important representative of the National Baptist Association, the body of Afro-American mission, in Natal. When Shembe started proselytizing in Natal from 1908 onward, himself certified as minister of Lashega's Baptist church, he took over the remnants of Mfazwe's congregations, a process reflected in the location of two important

25 Excerpts are contained in: Robert Papini/Irving Hexham (eds.), The Catechism of the Nazarites and Related Writings, Sacred history and traditions of the Amanazaretha 4, translated by HANS-JÜrgen BECKen/Phyllis ZUNGU, Lewiston 2002, 186-220. I also had access to two later renditions of the founder's life in church writings: MTHEMBENI MPANZA, UShembe nobuNazaretha: Isaiah Shembe's Summarized Biography, Ebuhleni no date (37 page photocopied typescript, available at the Killie Campbell Library, Durban) and Anonymous, Ukuzalwa kuka Shembe, Ebuhleni no date (8 page photocopied typescript, which I bought in Ebuhleni in 2009).

26 Papini/Hexham (eds.), Catechism, 195.

27 Op.cit. There is an extended version in MPANZA, UShembe, 9-10; the much shorter version in Anonymous, Ukuzalwa, 2-3, does not mention Shembe's clothing. Christian Wetz suggested that Shembe's clothing might refer to that of John the Baptist (Mark 1:6), but I think that the opposition with mission Christianity here, as well as the following examples make clear that in these stories clothing functions as a marker of difference via African cultural traditions.

28 Papini/Hexham (eds.), Catechism, 198. The story is missing in Mpanza, UShembe, in Anonymous, Ukuzalwa, $5^{-6}$, the prophet is called Mfazo, but the prophecy is exactly the same. The part of the prophecy referring to the greater one coming refers to the Bible (Mark 1:7). My thanks to Christian Wetz for the reference. 
temples of the NBC. ${ }^{29}$ Again, the story linked Isaiah Shembe's success, this time as missionary in Natal, with precolonial African traditions, dancing and clothing.

Johannes Galilee Shembe, son and successor of Isaiah, linked the origin of the church with African traditions as well. In the 196os, he explained to Hans-Jürgen Becken that in 1910 Isaiah "had converted a first group of 40 to $5^{0}$ heathen at Botha's Hill, and brought them to the American Board Mission to be cared for and eventually to become members of that church. But the African minister refused to take the people as they were-in their poor traditional clothes - and Shembe, therefore, felt that he himself had to take care of these people." 30 Johannes suggested that the growth of the church, which had accelerated during his leadership, rested on the fact that it appealed to the poor, "While they like European garments, many cannot afford them. No other church would accept people in their heathen dresses." ${ }^{31}$ In a Sabbath sermon in 1969, Johannes reconstructed the church founding. He stated that Isaiah left the Wesleyans because they did not baptize by full immersion and the Baptists because they wore shoes in church. Then "he established his own church, where he was different from all the other pastors, white as well as black. So he worked out our way of doing things, we of Ekuphakameni."32 This way expressed itself in African attire. "At that time when people wished to become Christians, they had to put on clothes. But Shembe read about Adam and Eve in the Bible. [...] I do not know where the pastors and missionaries took their teaching. What I know, I know according to the Bible. When God created our first parents, he made coats of skin and made them put these on. And Shembe said 'Let anybody who so wishes come in ibeshu or isidwaba." 33 Looking at fifty years of NBC history, Johannes used African attire to symbolize the fit between the founder's message and the interests of the laity, as a mark of difference that made a difference in relation to the other churches, the competitors in the religious field.

Isaiah Shembe was socially predisposed to express the latent dispositions of a section of the laity because he was like them: he was not Mission-educated, he had been the head of a polygamous household, and colonial prosecution and war had disrupted his life twice. His followers invested him with symbolic

\footnotetext{
29 Cf. Heuser, Soldaten, 189-190.193-196.

30 Hans-Jürgen Becken, The Nazareth Baptist Church of Shembe, in: Hans-Jürgen Becken (ed.), Our Approach to the Independent Church Movement in South Africa, Mapumulo 1966, 101-114, here 103 .

31 Op.cit., 108.

32 Bengt SundkLer, Zulu Zion and Some Swazi Zionists, London 1976, 169.

33 Ibd.
} 
capital, with charisma, with extraordinary, miraculous power. However, when he became a Christian healer in that Wesleyan church "he was still wearing traditional garb; it was before he wore trousers" and he was shocked to be called upon to lead the service because "he had always been the man in the back in his skin loincloth (ibheshu)" 34 . In the trope of the African attire, the church traditions emphasize that despite his tremendous spiritual power, their leader was one of them.

According to Bourdieu, influence over the laity "must be paid by a redoubling of the concessions granted [...] to the religious representations of the laypersons thus conquered"35. Isaiah introduced two practices, dancing in African attires and Sabbath worship, that can be interpreted as such concessions. Isaiah had opposed dancing, and installed it as a form of worship around 1919 only, as people with rural, non-Christian background, increased in number and importance within his congregation. ${ }^{36}$ With the exception of the young men's Scottish (isikoshi) outfit, all attires were neo-traditional African by the 1930s. People danced to the church hymns, whose music followed the precolonial clan and regimental dance hymns. The texts, outstanding examples of early modern Zulu poetry created by Isaiah, combined biblical themes with a lament of Zulu history and millenarian hope. For the church members, dancing became a central practice, a this-worldly exercise of the way to paradise, as expressed in Hymn 124, "I shall sing with joy in the holy village, my heavenly escorts will rejoice at my entrance. I shall dance for him who is praiseworthy, I shall not be shy. Lift up, oh gates, lift up that we may enter."37 The performance of the dance created cultural meaning as it actualized cultural traditions through the actors' positionality. ${ }^{38}$ This positionality was relational. Dancing related to the dispositions of lay members who enjoyed dancing in other contexts, it united them in the dance groups, and directed them towards their leader, as dancing took place on command of the leader only. And it positioned the Nazarites in the religious field. Among the AICs only members of the NBC danced in neo-traditional attire. Dancing made a difference and marked the radical break with mission Christianity. The church's sacred dance,

\footnotetext{
34 Papini/Hexham (eds.), Catechism, 194.

35 Pierre Bourdieu, Genesis and Structure of the Religious Field, in: Comparative Social Research 13 (1991), 1-44, here 29.

36 Cf. Heuser, Soldaten, 224-227; cf. also Robert Papini, The Move to Tradition: Dance Uniform History in the Church of Nazareth Baptists, in: African Art 29 (2004) 3, 48-61, here $49^{-} 5^{2}$.

37 Carol Muller (ed.), Shembe Hymns, translated by Bongani Mthethwa, Scottsville 2010, 131. Cf. also Sithole, Shembe's Hymns, 66-72.

38 Cf. Bнавна, Culture, 53.
} 
"immediately recognizable as Zulu holy dance (ukusina)", turned into the most attractive part of the "Nazarite bricolage [...] spelling out a biblical creed with African identity [...] that had boldly broken with mission and derived (Ethiopian) norms"39. It made the NBC unique and attractive, and contributed to its success.

Another practice that made a difference was the observance of the Sabbath. Joel Tishken suggested that Isaiah was convinced of the centrality of the Sabbath for salvation by 1906, and instituted it right from the beginning of the NBC in $1910 .{ }^{40}$ In contrast, Heuser argued that the shift occurred in the early 1920s, in order to incorporate the followers of prophet Johane Zandile Nkabinde into the $\mathrm{NBC}{ }^{41}$ While the exact date is not that important, my sociological argument rests on the contextualization provided by Heuser. In the religious field of southern Africa in the first decades of the 2oth century, Sabbath worship connected with political radicalism and epitomized the whites' fear of the dangers of African Independency, and its introduction connected with the dispositions of the millenarian minded sections of the laity. Like dancing, the observance of the Sabbath leads to salvation: "Sabbath is the key, the gate is now open" (Hymn 212). ${ }^{42}$ And the hymn of the Sabbath liturgy, performed weekly, urges the congregation to praise Jehovah "with drums and sacred dance. [...] with drums that are powerful", because "[h]e made us reign over the homesteads of our enemies. [...] He scattered them with an arm that is omnipotent" and turned "slavery into a kingdom, because his mercy endures forever." 43

Thus, by the 1920 s at the latest, the NBC practiced Sabbath worship and sacred dance. These practices made the church attractive to rather disparate sections of the laity, sections that lay beyond or actively resisted the appeal of Mission Christianity. In political terms, the program of the NBC could attract followers of the Inkatha ka Zulu, conservative Zulu nationalists aiming to restore power to king and chiefs, as well as those of the Industrial and Commercial Workers' Union (ICU), socialists promising liberation for African workers dispossessed of their land. ${ }^{44}$ These movements shared, despite their open conflict, the challenge to white rule in South Africa. Correspondingly, Isaiah Shembe publicly proclaimed to be the prophet foretold by one of the

\footnotetext{
39 PAPINI, Move, $5^{2}$.

40 Cf. Joel E. Tishren, The Nazareth Baptist Church as Subordinationist Christianity, in: AfS 74 (2015) 3, 449-469, here 459 .

41 Cf. Heuse R, Soldaten, 111-117.

42 Muller (ed.), Shembe Hymns, 193.

43 Op.cit., 25-26, 37.

44 Cf. Heuser, Soldaten, 98.185-186.
} 
leaders of the 1906 Zulu revolt, Messen Qwabe, who would "revive the bones of Messen and of the people who were killed in Bambatha's Rebellion"45. This constituted the socio-cultural context of the rise of the NBC, and Isaiah Shembe's outstanding ability to draw upon it, exemplified in the Sabbath and the dancing, made his charisma and the success of the church. While his position as a healer was important, he did not become a church leader because he healed, but he healed because he had become a church leader, as in Claude Lévi-Strauss' explication of the social character of the sorcerer's magic. ${ }^{46}$

Did Isaiah present himself as the Messiah? Did his followers represent him as such? In Hymn 34 Isaiah suggested that the coming of Christ as related in the bible was happening again in eKuhakameni, located the hills of Ohlange: "There came the wise ones, coming from the East. They said, 'Where is the one who is the King of the Jews?' It is like that today on the hills of Ohlange."47 Hymn 71 proclaimed that spiritual entity Shembe is older than creation: "My Lord, you have loved me before the mountains had solidified; from eternity you anointed me, I am the beginning of your path."48 One of the foundational narratives of the NBC is the story of how Jehovah made covenant with Isaiah on the holy mountain iNhlangakazi, an event the church commemorates with a pilgrimage to the mountain every year. According to one version of the story, numerous spirits approached Isaiah on the mountain and asked whether he has come for them, but he rejected them all, until finally Jehovah appeared. Jehovah anointed Isaiah and told him, "Go and teach all nations the way of God to heaven; Jehova is making a covenant with the black people."49 In a later rendition, Hymn 71 was inserted at the point where Jehovah anoints Isaiah. ${ }^{50}$

The topoi introduced in the hymns continued to inspire reinterpretations in church performances. In a sermon in 2009, Evangelist Cele told the story of white astronomers who followed a star falling into the hills of Ohlange, which foretold the coming of the Black Messiah, whom they, as whites, could not follow. Then he sang verse 2 of Hymn 139, "He has arrived, who is spoken about by

45 SundKLER, Bantu Prophets, 313.

46 Cf. Claude Lévi-Strauss, The Sorcerer and His Magic, in: idem, Structural Anthropology, translated by Claire Jacobson/Brooke Grundfest Schoepf, New York 1963, 167-185, here 180 .

47 Mulle r (ed.), Shembe Hymns, 73. Cf. also Sithole, Shembe's Hymns, 53-55.

48 Op.cit., 97.

49 Papini/Hexham (eds.), Catechism, 209. The oral traditions are problematic as historical sources, because they can hardly be dated. For my argument here the representation is important, even if its source can be dated to 1975 only (op.cit., 180). It remains unclear how old the traditions on the covenant are, but the pilgrimage started in 1913, according to church traditions.

50 Cf. Mpanza, UShembe, 25. 
the prophets. Acclaim him, you men, acclaim him, all nations."51 Cele continued with a second story in which a mission Christian died and went to heaven where she met the spiritual Shembe. She could not enter his heavenly house, because she was not a church member, and Shembe sent her back to earth, where she had to wait for nine years, until Shembe on earth had finally founded the NBC, in order to gain salvation. With his narration of events taking place before the foundation of the church in 1910, Cele emphasized that "as Nazarites we know that Shembe had always been around"52. Daniel Dube told a similar story, in which Shembe sends back a Roman Catholic woman, who was refused entry into white heaven, so that she could enter the NBC and gain entry into black paradise. ${ }^{53}$ Phumile Maphumulo recounted how two white English maidens, also Roman Catholics, arrived at eKuphakameni. They had prayed "that Jesus should come back to them. But he had said that he would not come to them, because he had now gone to a nation with curled hair like sheep, where he wanted to work among this nation." Jesus then gave the women detailed instructions on how to reach eKuphakameni, but warned them that "he would not look like we knew him (from the pictures) and have other hair". When they met Isaiah, they were satisfied, because "they had now seen the man for whom they undertook this their long journey"54.

\subsection{Hereditary Charisma and Traditional Authority}

Isaiah had been an immensely talented leader, who mixed messianic traits with cultural politics, but the most critical point in the history of charismatic movements is the death of the founder. Isaiah had appointed Johannes, his son, as his successor. Only after Isaiah's death did Johannes discover "that he, also, possessed the gift of healing", and "[h]is ability to carry on this branch of his father's work has done a great deal to strengthen his position as head of the

51 Muller (ed.), Shembe Hymns, 141. The man foretold by the prophets is called "the Willing One" and "the Comforter" in the Hymn, and the last verse states "[i]t was said that we would never be left alone, he has arrived". In his sermon, Cele identified the somewhat ambiguous figure from the hymn with Isaiah Shembe, and by extension, with the Shembe present at the service, Vimbeni. And he was less ambiguous, as the white astronomers of his story identified Shembe as Black Messiah (umumesia umnyama). Evangelist CELE, Sabbath Sermon, transcribed by Sicelo Mpungose and translated by Zakhona Maduna, eBuhleni, 31st January 2009.

52 Ibd.

53 Cf. Irving Hexham/G.C. Oosthuizen (eds.), The Story of Isaiah Shembe: History and Traditions Centered on Ekuphakameni and Mount Nhlangakazi, Sacred History and Traditions of the Amanazaretha 1, translated by HANS-JÜRGEN BECKEN, Lewiston 1996, 132-134.

Op.cit., $182-183$. 
church". ${ }^{55}$ Nevertheless, he had to establish and defend his charismatic authority in the face of doubtful ministers and renegade charismatics. ${ }^{56}$

Johannes' decisive strategy that shaped the further history of the NBC was to claim that he had inherited the spiritual power of his father, and that the singular and eternal spiritual entity "Shembe" resided in him now. He stakes his claim in Hymn $220 .{ }^{57}$ The song's voice laments Isaiah's death, but verse 6 to 9 cite Isaiah's last prayer, in which he asks God not to "forget your people, the Holy Nazaretha" as well as to "[r]aise up someone else in my house to lead your people"58. Isaiah's prayer closes with a reflection about his future and ontological status, "My flesh is weary, it will lie in the grave, my spirit will rise and be clothed with a new flesh. I was born in eternity, at all times I shall be there."59 With this hymn, Johannes Shembe had introduced the full conceptualization of hereditary charisma in the NBC: The eternal spiritual Shembe would rise in someone of his house (endlini), i.e. in one of his descendants. As part of the hymnal, the most widespread text in the NBC, it enjoyed lasting impact. ${ }^{60}$ In 2011, at Vimbeni's memorial service, when chief Mqoqi Ngcobo had just announced Mduduzi as successor, and the congregation reacted with shouts of "You are holy! Amen!", Reverend Vilakazi, the master of ceremony, citied verse 7 of hymn 220 and concluded, "These great words speak of the thing that has just happened." 61

Johannes Galilee had to prove his charisma through miracles, and this proof came in the form of the followers' testimonies. Meshack Hadebe conducted a systematic test. Just after Isaiah's death, when people doubted the power of the successor, he demanded that "[w]e mustn't be afraid to test God through his own Galilee Shembe." ${ }^{2}$ They prayed over a sick woman, "You Galilee, Lord of

55 Roberts, Shembe, 111.

56 Cabrita, Text, 193-195.310-311; Heuser, Soldaten, 120; Andreas Heuser, Contested Charisma: Reflections on the Appearance and Disappearance of Female Visionary Power in a South African Independent Church, in: Zeitschrift für Globalgeschichte und vergleichende Gesellschaftsforschung 17 (2007) 5/6, 76-94, here 80-81.

57 In the first printed publication of the hymnal in 1940, Johannes claimed that the resurrected Isaiah authored the hymns 220-222, but from the second edition in 1948 onward, the introduction to hymn 220 read as "written by J.G. Shembe in January, 1938, on top of the Mountain of Nhlangakazi". Cabrita, Text, 209-210; Muller (ed.), Shembe Hymns, 199 .

58 Op.cit., 201.

59 Ibd.

6o Cf. CABrita, Text, 213 .

61 Joseph J.M. Vilakazi, Speech at the funeral of Vimbeni Shembe, transcribed and translated by Sicelo Mpungose, Ebuhleni, 3rd April 2011.

62 Liz Gunner (ed.), The Man of Heaven and the Beautiful Ones of God: Writings from Ibandla lamaNazaretha, a South African Church, Leiden 2002, 195. 
lords, full of compassion, kindness and love. You through whom we can pray $[\ldots]$. You who are always seated among the angels, Father Shembe of surpassing beauty, have mercy on us. [...] Cleanse her[,] Lord[,] and restore her to health" 63 . As the intervention drove out the demons successfully, it proved that "the new leader is still the very one whom you say has gone."64 The large number of testimonies attested to Johannes' success in establishing his charismatic authority as church leader, and some of them identified him as the Messiah positioned in the racialized context of Apartheid South Africa ${ }^{65}$ Abednego Mthemu told the story of a young woman coming into the church to ask for children in 1949. She asked the church members who they thought their leader was, and when they replied "Shembe", she said, "Your eyes are very blind; I know already for three days that he is Jesus. You are just misled by his skin.' Then we understood that she had received a revelation."66 Musa Khuzwayo recounted his own visionary dream from 1956 in which Johannes appeared "as a White with long hair hanging down like a Jew. Then he changed his pigmentation and looked like an Indian. In the end, he turned Brown, as we know him. $[\ldots]$ Then I was convinced, that he is not an average human being; rather he is Jesus Christ-even if people say he is not." 67

The death of Johannes made it obvious that he successfully established hereditary charisma in the NBC, but also showed the main drawback of the concept, as two of Isaiah's descendants competed for leadership. Both Amos, Johannes' half-brother, and Londa, his son, claimed to have received the charismatic ability from Johannes/Isaiah, but I have argued elsewhere that Amos succeeded through his networking rather than his charisma. ${ }^{68}$ In the wake of the church schism, the oral traditions adapted to the positionality of the new leader. One claimed that Isaiah had predicted that after the sun (iLanga, Johannes Galilee Shembe) set, the moon (iNyanga yeZulu, Amos Shembe) would rise, and the new version of the founder's biography included a section in which God commands Isaiah to return to his wives twice in order to sire first Johannes and then Amos, the future lords of the Nazarites. ${ }^{69}$ Likewise,

63 Op.cit., 195.197.

64 Op.cit., 193. See also Cabrita's discussion, CABrita, Text, 210-211.

65 Many narratives of miracles performed by Johannes and Amos Shembe are collected in: Irving Hexham/G.C. Oost huizen (eds.), The Story of Isaiah Shembe: The Continuing Story of the Sun and the Moon, Sacred History and Traditions of the Amanazaretha 3, Lewiston 2001.

66 Op.cit., 29.

67 Op.cit., 46.

68 Cf. ECHTLER, Worship, 388.

69 Cf. Heuser, Charisma, 93; cf. also Mpanza, UShembe, 16 . The other version did not contain that story, but one about Isaiah Shembe being killed by lightning and instructed by 
the conceptualization of the leader's charisma in the members' testimonies changed. Jesus moved into the background, and the main emphasis was on the continuity, cooperation or indeed identity between Amos, Johannes and Isaiah. Rather programmatically, Vimba John Magubane's testimony provided visionary support for Amos' claim. "There I saw an astonishing thing: and I was not dreaming: When the Moon entered, he was surrounded by the Beginner of the Way and the second lord. He opened the service and said: 'I do not walk here alone today; there are the two on both sides. They have told me all what I am going to say."'70 Again, the production of meaning depended on the actors' positionality. Regarding the hereditary charisma, Amos had to establish his line of descent as the legitimate one. His conflict with Londa led to the breach between his descendants, the house of the Moon located in eBuhleni, and those of Johannes, the house of the Sun, located in eKuphakameni. This schism formed the trauma in the history of the NBC, and its drama has been replayed in all the successions in the eBuhleni branch since.

When Amos died in 1996, his son Vimbeni succeeded him. Recalling the succession, Nonhlanhla presented the paradigmatic aspects of the leader's charisma, acknowledgement and healing: "We just heard the praising [uyingcwele - You are holy], and later on we heard that a blind person had been saved, that his eyes had been opened. [...] The same thing happened during iLanga's [the sun: Johannes Galilee] and uMqaliwendlela's [the founder: Isaiah] era." ${ }^{71} \mathrm{~A}$ son of Johannes had contested leadership, but failed to gather support, whereas Vimbeni found support in the story that the moon followed the sun in church leadership, as well as in a sermon that claimed that in the fourth leader "the first body has returned"72.

In 2017, I heard the same argument with regard to the fifth leader. Church members told me that obviously the founder had returned, because Mduduzi was doing the same things, most notably leading the congregation to a (new) holy mountain, and leading them on foot on the journey, something that Isaiah had done, but none of the leaders since. His performance made quite an impression on the congregation, especially as the change came as a surprise. In a Sabbath sermon on the new holy mountain, iKhenana, Mduduzi recalled the joint experience: "One of the difficulties we experienced in 2014 was that policemen and community members assumed that we were going to the old

God in heaven, which specifies that from that point onward there were three Shembes inside Isaiah. Cf. Anonymous, Ukuzalwa, 4.

70 HeXham/Oosthuizen (eds.), Sun, 68.

71 Interview with Nonhlanhla (alias), transcribed and translated by Sicelo Mpungose, eBuhleni, 23rd July 2008.

72 Heuser, Charisma, 93. 
mountain as usual. They forgot that we are being led by God. To their surprise we took a different route. Some of you were also confused. But you had courage to follow."73 With the claim of re-presenting Isaiah, Mduduzi managed to turn the disadvantage of giving up the site where Jehovah made covenant with Isaiah into an event that supported his charismatic authority.

However, a major factor in the succession conflict between Mduduzi, son of Vimbeni, and Vela, another son of Johannes, was traditional authority and the role of the chiefs in the NBC. At the memorial function for the late Vimbeni, the chief of the Qadi declared that Mduduzi was the new leader. He said, "Today I will do what my father did in 1977, when he gave the staff to iNyangayezulu [Amos Shembe] when they were returning from Nhlangakazi [the church's holy mountain] and he said to him 'Father Nyangayezulu, please take this staff and lead the people'. He took the staff and led the people. He was appointed [wabekwa] by the chief of the Qadi, my father Muzonjani Ngcobo. [...] As a chief of the people, I have every right to conclude: Nazarites, your leader is Mduduzi Shembe."74 This announcement was greeted with shouts of "Amen! You are holy!" from the congregation. While Vela won in court, Mduduzi strengthened his position through an alliance with the Zulu king, Goodwill Zwelithini kaBhekuzulu, who attended a Sabbath service atop the new holy mountain in January 2017-three months after the court ruling an unequivocal public acknowledgement of Mduduzi's leadership. In his speech he praised the church's holy mountain, pointing out the significance of mountains to Moses and Jesus, as well as their importance in Zulu culture and history, citing as an example the battle of Isandlwana, the most famous Zulu victory in the Anglo-Zulu war of 1879 , which took place on a mountain in January. ${ }^{75}$

While the importance of traditional authority has increased within the $\mathrm{NBC}$, this process goes back to the time of Isaiah, and represents one of the options of how to routinize charisma. ${ }^{76}$ From the 1920 onward, Isaiah cooperated with Zulu chiefs, which benefitted both sides, as the church's teachings turned obedience to the chiefs into a "spiritual virtue", while the support of the chiefs enabled Isaiah to win over the rural areas and turn his church into "an

73 Mduduzi Shembe, Sermon at Sabbath service, transcribed and translated by Brilliant Mbedu, eKhenana, 21st January 2017.

74 Mqoqi NGсово, Speech at the funeral of Vimbeni Shembe, transcribed and translated by Sicelo Mpungose, eBuhleni, 3rd April 2011.

75 Cf. Goodwill Zwelithini kaBekhuzulu, Speech at Sabbath service, transcribed and translated by Brilliant Mbedu, eKhenana, 14th January 2017.

76 Cf. WeBER, Wirtschaft, 142-143. 
institution of national standing"77. The Zulu king, Solomon kaDinuzulu, acknowledged this increased standing when he married Isaiah's daughter Zondi in $1926 .{ }^{78}$ Respect for patriarchal authority became the hallmark of the NBC. In the 1940s a chief came "to the prophet's place, not in order to become a Nazarite, but to study the ways of imposing inhlonipho (Zulu word for respect) on his people"79. Whenever church members met with Isaiah Shembe, they fell to their knees and shouted "Uyincwele!" (You are holy!), and addressed him as father or lord. ${ }^{80}$ Lord, inkosi, is the title of the leader of the church, as well as of Zulu kings and chiefs. At church gatherings I attended, the leader of the church was frequently addressed as "inkosi yamakosi", lord of lords. This referred to the biblical king of kings and proclaimed messianic status, but it also reflected the ritual proceedings. The Zulu chiefs, seated in the front row, in front of the ministers, evangelists and preachers of the church, acknowledged Shembe, at the center of the congregation, as their spiritual leader, as the chief of chiefs. This ritual representation carried some sociological truth, as the alliance with the chiefs proved a decisive factor in times of succession conflict.

Isaiah Shembe complemented his conservative turn by declaring ICU membership as sinful, and expulsing church members who refused to leave the union. ${ }^{81}$ His anti-union stance, along with his assurance to teach his "followers to obey the authorities placed over them, and to pay their taxes cheerfully" 82 improved his standing in relation to state power. While the church was still under surveillance, it was hardly considered a threat by the end of the 1920s. A 1929 newspaper article considered the church's festival "an exposition of how the Bantu may be raised up without becoming exotics, or mental or moral snobs [...] an epic of Zulu pageantry in which 50 chiefs and many hundreds of warriors in national regalia of skins and plume made an impossible sight" ${ }^{\prime 3}$. According to Robert Papini, this white voice represented exactly "segregationism's crusading rhetoric" 84 , but he also pointed to Isaiah's skill in managing the representation of the church and himself towards outsiders, a skill that reflects in the representation in academic discourse.

77 Joel Cabrita, Politics and Preaching: Chiefly Converts to the Nazaretha Church, Obedient Subjects, and Sermon Performance in South Africa, in: JAfH, 51(2010), 21-40, here 22.27.

78 Cf. Cabrita, Text, 260.

79 SUNDKLER, Bantu Prophets, 111.

8o Cf. Dube, Ushembe, $98-99$.

81 Cf. Cabrita, Text, 272; cf. also Heuser, Soldaten, 100.108.

82 Papini, Shembe's testimony, 250.

83 Op.cit., $25^{2-253 .}$

84 Op.cit., 252. 
In the 1910s, when white missionaries complained about Isaiah Shembe's activities, they often emphasized that he was "under no European authority"85. For African Christians and mission-educated intellectuals, being outside white control was rather desirable, so they questioned Isaiah on theological grounds. In 1930, representatives of mission and independent Christianity debated the "enigma" Shembe in "Ilanga lase Natal", the newspaper founded by John Dube. Amos Shembe, educated at Adam's College and working as a teacher in Dube's school at the time, had started the debate by claiming that his father's success rested on showing black people their own way to God. ${ }^{86}$ When challenged to explain why Jesus Christ did not feature in Isaiah's teachings, Amos explained the silence on cultural grounds: In Zululand it would be extremely disrespectful to praise the son while the father was still alive, therefore to put the son in the center would disdain God, while to raise the father would not belittle Jesus. Others supported this interpretation with critiques of Eurocentric representations of Christ, but there was also critique of Amos' use of culture, with one opponent pointing out that in Zululand a person disobeying the king's command to praise his son would be thrown off a cliff. 87

While Amos tried to explain away the silence on Jesus, there were corresponding silences in Isaiah's self-representations vis-à-vis whites and black intellectuals. ${ }^{88}$ Compared with the "Book of the Birth of the Prophet Shembe" produced for in-church readership, the accounts aimed at outsiders lacked the foundational narratives of the NBC's most important sacred sites, eKuphakameni and iNhlangakazi, and thus Isaiah's divine mission: "Go and teach all nations the way of God to heaven; Jehova is making a covenant with the black people." 89 Papini suggests that Isaiah "chose to avoid pressing too forcefully his full prophetic claims/credentials" 90 when trying to build credibility with whites and Christian competitors.

Measuring these silences, they seem to center around Isaiah's messianic claims. The Isaiah from the church traditions, the illiterate Black Messiah in skin girdle, is the silent subject serving as "counterpossibility for the narrative

\footnotetext{
85 Elizabeth Gunner, Power House, Prison House: An Oral Genre and its Use in Isaiah Shembe's Nazareth Baptist Church, in: JSAS 14 (1988), 204-227, here 217.

86 Cf. Heuser, Soldaten, 182.

87 Cf. op.cit., $205^{-207 .}$

88 Isaiah told his life to various state officials during the 1920s, as well as to John Dube who used it in Isaiah's biography. Cf. PAPINI, Shembe's testimony, 254.

89 Papini/Hexham (eds.), Catechism, 209.

90 Op.cit., 184. Cf. also Sithole, Shembe's Hymns, 49.
} 
sanctions granted to the colonial subject in the dominant groups" ${ }^{\prime 1}$ of the respectable, bourgeois kholwa Christianity.

The epistemic violence involved in Isaiah's messianic claim was drastically expressed in a polemic directed against the NBC, according to which "Isaiah Shembe died of an accident in which he had created artificial wings and attempted to fly (imitating Jesus) from Nhlangakazi and did not make it." ${ }^{\text {92 }}$ In the version I heard, there was the added insult that dogs, impure animals forbidden within the church, ate his corpse. Within the NBC, this story was commonly attributed to John Dube or his newspaper "Ilanga lase Natal", though young church intellectuals explained to me that it really originated with church dissidents, according to a sermon given by Johannes Shembe. ${ }^{93}$ Nevertheless, the newspaper warned of church leaders reenacting the Bible and published articles that criticized Shembe's turn to African traditions as inciting "greed for money and power and bodily pleasure" 94 , a critique that mirrors the judgement of a state official who considered Shembe's work as "personal aggrandizement under the cloak of religion" 95 .

Given that epistemic pressure, Johannes Shembe managed outside relations of the church by declaring notions of the messianic character of Isaiah or himself to be the belief of lay members only, to be distinguished from the true teachings, while concealing his own and his father's efforts to propagate these very notions. In 1941, he told Sundkler, "Some of our people say 'Shembe is God'. But no, Isaiah never wanted to accept that." ${ }^{\prime 6}$ In 1958, a native commissioner reported that "[n]either Isaiah nor Galilee have represented themselves to be the reincarnation of Christ, but many members of the congregation believe this to be the case"97. In 1965, Johannes told Becken that leadership of the NBC was not hereditary, and that after being appointed leader, John Dube and an old woman introduced him to his new work. Becken writes, "His high education greatly helped J.G. Shembe to understand better what his father had taught. Many of the church members in their ordinary mind did not understand what I. Shembe was teaching, and even today many of them are guided more by

\footnotetext{
91 SPIVAK, Subaltern, 82.

92 Nkosinathi Sithole, Decolonizing the Word: Themba Masinga and his Religious Poetry in Ibandla LamaNazaretha, in: Religion 45 (2015), 191-208, here 195.

93 Interview with MzWANDILE and BHEKINKosi (aliases), transcript by author, Durban, 21st March 2009.

94 HEUSER, Soldaten, 118.183.

95 PAPINI, Shembe's testimony, 255, n51.

96 SundKLER, Zulu Zion, 196.

97 CABrita, Text, 212.
} 
superstition than by his actual teachings." 98 Johannes explained that "[i]t is not true that the Church replaces Christ by Shembe. We regard Christ as God, as equal with God, and not, as we are sometimes accused, as subordinated to God, or as the Messiah for the Whites." 99 With this information, Becken drew the following conclusion in his paper presented at the Umpumalo Lutheran Theological Institute: "Real Christian aid could be given to this movement by providing for an adequate ministry, which could do away with the superstitions of the church members and develop it according to true Christian principles."100 Given that start, it is kind of ironic that Becken ended up translating the members' testimonies and thus enabled the publication and widespread reception of their "superstitions".

During Johannes Shembe's reign, the NBC entered academic discourse. In his "Bantu Prophets in South Africa", first published in 1948, Sundkler passed a clear theological judgement. "What once happened through Jesus, among the Jews and for their salvation, is now being re-enacted through Shembe, among the Zulus and for their own salvation. Through this repeated revelationwhich is the secret of all syncretism-Shembe is represented as the Christ of the Zulus"101 is the meaning of Hymn 34, according to Sundkler. He considered "the omission of the name of Jesus or the Son" as significant and added that "[i]n the belief of his followers Shembe becomes co-creator with God, and he is the mediator in heaven"102. He regarded the NBC as the most important representation of "the Black Christ ideology", and as such had the NBC in mind when he warned in conclusion that the "syncretistic sect becomes the bridge over which Africans are brought back to heathenism"103, a judgement that gave the concept of syncretism its bad name in the study of African Christianity. ${ }^{104}$

In the late 196os, Gerhardus Oosthuizen followed Sundkler's interpretation. In his analysis of the NBC hymns, he argued that "Shembe I [Isaiah] is not only Mediator but is Messiah, the manifestation of God"105. In a comparative work, he suggested that "Shembe himself developed into a Zulu messiah

\footnotetext{
98 BECKEN, Nazareth, 107.

99 Op.cit., 108.

100 Op.cit., 114.

101 SUNDKLER, Bantu Prophets, 284.

102 Op.cit., 283.285.

103 Op.cit., 281.297.

104 Cf. Afe Adogame/Magnus Echtler/Ulf Vierke, Introduction, in: Afe Adogame/ Magnus Echtler/Ulf Vierke (eds.), Unpacking the New: Critical Perspectives on Cultural Syncretization in Africa and Beyond, Beiträge zur Afrikaforschung 36, Berlin 2008, 1-23, here 6 .

105 Gerhardus Cornelius Oosthuizen, The Theology of a South African Messiah: An Analysis of the Hymnal of the "Church of the Nazarites", OeS 8, Leiden 1967, 4.
} 
who became the God of the Blacks in their hunger for realized revelation. He is in a real sense their Moses, their real personification of Zulu kingship", and concluded that " $t]$ he movement of Shembe-the outcome of the meeting of two cultures and two religions-has developed doctrinally into a syncretistic post-Christian movement"106.

These interpretations, rather hybrid affairs, in which white scholars, from the position of academic authority, ejected the NBC from the Christian fold based on the ascribed Messianic status of Shembe, formed rather obvious targets for critical postcolonial readings. The first critique, however, originated in the colonial center, as Sundkler reconsidered his interpretation. Isaiah Shembe is no longer the Black Christ but rather the "African prophet turning to God's black people [...] privileged to wear [...] the mask of the Black Christ"107. Thus hymn 34, with Shembe re-enacting Jesus, acquires a new meaning: "God in his wisdom is now using his Bantu mask as he returns to his Black children."108 Sundkler criticized Oosthuizen for misunderstanding the hymns, because he interpreted them from "the presuppositions of Luther's catechism or that of Heidelberg", and not from "the needs and aspirations of the Zulu in the context of a race-ridden South Africa"109. Sundkler's own interpretation rested on the difference between "the prophet's own personal faith and expression of faith and the testimony of his followers"110. In his earlier publication, he distinguished between an official and an insider representation of Isaiah, claiming prophetic or messianic status, respectively, a difference that informed the way members communicated with Christian outsiders: " $[\mathrm{H}] \mathrm{e}$ is God, but in inhlonipho-language we call him prophet."111 But while Sundkler followed the insider representation in his earlier interpretation, he now privileged the official version. "Johannes Galilee Shembe has a right to be believed" when rejecting the statement "Shembe is God"112.

A second critique of Oosthuizen came from black South African scholars. In 1986, Absolom Vilakazi, with co-authors Bongani Mthethwa and Mthembeni Mpanza, accused Oosthuizen of misunderstandings and distortions based

1o6 Gerhardus Cornelius Oosthuizen, Post-Christianity in Africa: A Theological and Anthropological Study, London 1968, 36 .

107 SUNDKLER, Zulu Zion, 193.

108 Op.cit., 200.

109 Op.cit., 195.

110 Op.cit., 193.

111 SUNDKLER, Bantu Prophets, 286.

112 SUNDKLER, Zulu Zion, 196. For Johannes presenting the official version to Sundkler, or in the presence of Sundkler, see also op.cit., 163.170. 
on "his improper grasp of the Zulu language and [...] Christian bias"113. He argued that the "Christian theological obsession with the theme of the usurpation of Christ's place in African independent churches arises from western ethnocentric bias" and serves to discredit "non-western interpretations of Christianity"114. Against that obsession, he suggested that Shembe represented "a prophet in the nature of the biblical prophets", and, while allowing members testimonies as evidence for the "sacralization of Shembe", he considered it "unfair to blame Shembe I for what people, who came under his influence, said about him"115.

Another ten years after this re-interpretation, which in order to include the NBC in the Christian category downplayed Shembe's messianic status and thus privileged Johannes' official version over the members' perspective, the publication of the members' testimonies started, and the new church leaders held a different view. In the first publication of traditions from the NBC, Irving Hexham expected academic readers to be surprised to find an essay of Oosthuizen included, as he had been criticized "as an Afrikaner predikant, i.e. clergyman, who lacked sympathy for African Independent Churches"116. Therefore he emphasized that the current leaders, Amos and Londa Shembe, "have repeatedly told foreign visitors that Oosthuizen, not Sundkler and certainly not Vilakazi, correctly interpreted their theology"117. Londa explicitly addressed the epistemic pressures that made it near impossible to speak about who Isaiah Shembe or he himself represented. "We say Shembe is a Prophet to you Westerners because the truth would give you cultural and mental indigestion"118. With some frustration he wrote Hexham, "I made it plain to you again and again who I think Shembe was within the bounds of safety which the cultural domination permits me (at the cost of being called a lunatic) [...]. Think of me as being both Londa Shembe and Isaiah Shembe and then you will understand"119. To claim that the eternal, spiritual Shembe resided in him transgressed the "narrative sanctions granted to the colonial subject"120.

113 Absolom Vilakazi/Bongani Mthethwa/Mthembeni Mpanza, Shembe: The Revitalization of African Society, Johannesburg 1986, 89.

114 Op.cit., 113.

115 Op.cit., 104.

116 Irving Hexham, Introduction, in: Irving Hexham (ed.) The Scriptures of the amaNazaretha of Ekuphkameni: Selected Writings of the Zulu Prophets Isaiah and Londa Shembe, Calgary 1994, vii-xxii, here xix.

117 Ibd.

118 Op.cit., $\mathrm{xx}, \mathrm{n}_{5} 6$.

119 Irving Heхнам, Isaiah Shembe, Zulu Religious Leader, in: Religion 27 (1997), 361-373, here 366.

120 SPIVAK, Subaltern, 82. 
In linking it to the risk of being called a madman, Londa drew upon church history, with traditions recalling Anglicans reporting Isaiah to the magistrate as the "madman of Bhambatha"121, and historical records documenting state agents pondering the strategy of having Isaiah declared insane in order to stop him without violating the freedom of religion. ${ }^{122}$

By the late 1990s, then, the leaders of the NBC factions had started to represent church theology and the leaders' status in an official version that coincided more with the views of lay church members, whose polyphonic voices had become more accessible with the publication of the "Acts of the Nazarites". In order to see how the end of the silencing of the subaltern voices impacted on the theological discourse, I now turn to the subsequent works of four academics who discussed the status of the leaders of the NBC.

The work of Edley Joseph Moodley stands out not only because the standing of Shembe and Jesus within the NBC formed its central question, but also because it focused on current developments in the church and employed ethnographic methodology. ${ }^{123}$ According to his findings, "amaNazaretha members believe that the Holy Spirit that was present in Jesus Christ, Isaiah Shembe, Galilee Shembe and Amos Shembe is now resident in Vimbeni Shembe"124. Moodley managed to interview Vimbeni Shembe, who also answered a questionnaire in writing. Regarding the relationship between Shembe and Christ, Vimbeni explained that the "Holy Spirit that resided in Christ is the same Spirit in Shembe", and to the question who is more powerful, he replied "[ $t$ ] hat is like asking which side of the 20 cent coin is more valuable"125. On the identity of church members, he remarked that "we are not Christians. ... We are Nazarenes ... but we do follow the advices given by Christ."126 As the responses from ministers and laity proved to be rather similar, and his analysis of twelve Sabbath sermons yielded 48 references to Shembe versus three to Jesus Christ, Moodley concluded that the NBC does "not qualify as a Christward", but rather as a "post-Christian" movement, because "Shembe has replaced

121 Irving Hexham/G.C. Oosthuizen (eds.), The Story of Isaiah Shembe: Early Regional Traditions of the Acts of the Nazarites, Sacred History and Traditions of the Amanazaretha 2, translated by HANS-JÜrGEN BECKEN, Lewiston 1999, 241.

122 Cf. ECHTLER, Shembe, 241-242. While the strategy was apparently not put into practice in Isaiah's case, prophet Nkabinde was both imprisoned and held in a mental hospital. See Heuser, Soldaten, 112.

123 Cf. Edley Jose Ph Moodley, Shembe, Ancestors, or Christ? A Missiological Inquiry into the Status and Role of Jesus Christ in the Amanazaretha Church, Kwa Zulu Natal, South Africa, PhD Dissertation, Asbury Theological Seminary, Wilmore 2004, 9-17.

124 Op.cit., 154.

125 Op.cit., $344-345$.

126 Op.cit., 258. 
Christ"127. Within his academic, or epistemic frame, however, the conclusion that the NBC constitutes something new beyond Christianity required a missiological response, and he suggested "a discipleship program" in which "indigenous leader[s] trained in a Western seminary" would bring the NBC "back to orthodox faith"128. Both in theological conclusion and missiological response Moodley followed closely the work of Oosthuizen, who had suggested 30 years earlier that the theological education of the laity should be the response of the "evangelizing Church" in Africa to the challenge of post-Christianity. ${ }^{129}$

Andreas Heuser's work focused on Isaiah Shembe, and incorporated a wealth of historical data concerning the religious and socio-political context of the formation of the NBC. His interpretation emphasized Isaiah's ethic of nonviolence, which coincided politically and spiritually with that of Mahatma Gandhi, his contemporary in Durban, and which included the critique of both colonial and Zulu political power. ${ }^{130}$ According to Heuser, Isaiah was part of a wider "Christological fantasy" of a Black Christ who would liberate the Africans, but the label did not fit Shembe, because his own Christology "did not allow a usurpation of Christ through dynastic redeemers, nor did Shembe tolerate a millenarian profile in Christology"131, especially if combined with an ethnic or racial exclusivism. For his reconstruction of Isaiah's Christology, Heuser rejected the oral traditions of the church as unsuitable. ${ }^{132}$ Instead, he used Amos Shembe's representation of Isaiah in John Dube's newspaper, in which he explained the absence of Jesus, the son, in Zulu cultural terms (see above). ${ }^{133}$ As evidence for Isaiah's belief in the universality of Christ, he referred to the parable of the wheel, in which God is the in the center, and the different people along the outer edge, separate from each other, but all in the same distance to God. ${ }^{134}$ Shembe told this parable to Esther Wells, a white journalist, whom Papini characterized as "ardent admirer and champion" of Shembe, as well as to Esther Roberts, a white academic, in whose work on Shembe the parable is immediately preceded by another of Isaiah's teachings, namely that " $t]$ he Whites $[\ldots]$ are the fathers and we are the children". 135 Thus, Heuser followed the inclusive paradigm and privileged the representation for outsiders over those by

\footnotetext{
127 Op.cit., 303.313.

128 Op.cit., 320.327.

129 Cf. Oosthuizen, Post-Christianity, 255.

130 HEUSER, Soldaten, 292-294.

131 Op.cit., 205.208, my translation.

132 Op.cit., 206, n88.

133 Op.cit., 205-207.

134 Op.cit., 208.

135 PAPIni, Shembe's testimony, 252; Roberts, Shembe, 43.
} 
and for church members. While Heuser's work centered on early church history, he also discussed the representation of Shembe in post-apartheid South Africa. He argued that the notion of the Black Messiah originated in Mission Christianity and missiology "as an othering discourse to exclude Shembe from [...] orthodox Christian faith in Africa"136, but was also appropriated by some church members, who combined messianic status with romantic visions of African social revitalization. Since 200o, Black Messiah was "replaced by the notion of Shembe, "The African Messiah"137 by in-church factions consisting of "mainly ANC-related, predominately male und urban-based youth or student groups that master the political codes of African Renaissance."138 Against this politicization, Heuser emphasized the persistence of Isaiah Shembe's ethic of non-violence, especially in the minority branch of eKuphakameni.

Joel Cabrita pursued the question of "how spiritual legitimacy is generated by and through the work of church texts", primarily for the times of Isaiah and Johannes Shembe. ${ }^{139}$ Her main source were the published church traditions, the result of a cooperation between Christian academics wanting to locate the NBC "within a global communion of 'World Christianity", and the church leaders looking for an "international platform for disseminating news of the miracles of Shembe"140. With regard to the status of Isaiah, she analyzed how his performances strove to imitate the biblical Jesus, and argued that his "conviction that he was a latter-day Christ-a Zulu prophet sent by God to His Southern African people-was evident from an early point in his ministry"141. Through managing the church's production of text, Johannes later recast the concept with Shembe being "an incarnation of God's eternal spirit, the newest figure in the lineage of the biblical prophets such as Moses and Jesus Christ himself", and Johannes being "the latest incarnation of the Shembe spirit"142. Despite these post-Christian tendencies, Cabrita emphasized the deep "legacy of Protestant Christianity" within the NBC, providing the "intellectual and spiritual resources to write a new body of sacred texts", and rejected earlier interpretations over-emphasizing the importance of Zulu cultural traditions, or social scientific approaches centering on performance,

\footnotetext{
136 Andreas Heuser, Memory Tales: Representations of Shembe in the Cultural Discourse of African Renaissance, in: JRA 35 (2005), 362-387, here 368.

137 Op.cit., 370.

138 Ibd.

139 Cf. CABRita, Text, 347.

140 Op.cit., 32.

141 Op.cit., 159.

142 Op.cit., 206.
} 
practice or hybridity. ${ }^{143}$ Beyond her main focus, she presented the picture of a church in spiritual decline. Johannes, like Isaiah, "was regarded by his followers as the living incarnation of a biblical prophet". Amos was "a canny political player", under whose leadership the church allied with the ethnically exclusive politics of the Inkatha Freedom Party. The current leader, Mduduzi, "the phenomenally wealthy owner of a fleet of helicopters and businesses", oversees a church that has "skillfully positioned itself as a contemporary way of being African", offering "a smart, forward moving identity that promises social mobility for adherents via the blessings of Shembe"144. In conclusion, Cabrita linked the succession conflicts in the NBC since Johannes' death with an "increasing turn to African tradition" and ended with the suggestion that the survival of the church might depend on "a shift towards closing down of the canon before charismatic and textual dispute entirely split this great church apart"145. Thus her inclusive position with regard to the Christian character of the NBC seemed to be based on the church's textual culture rather than its Christology, and this over-emphasis, from my sociological view, on the importance of texts led to her rather pessimistic view of the recent history of the church.

The last academic discussed here is Joel Tishken. He is the only one who received his $\mathrm{PhD}$ outside theology, in history. In his thesis he compared the NBC with the Église Kimbanguiste, and concluded that although Kimbangu and Shembe "have replaced Christ as the last revealer of the Word, the belief in Christ as messiah remains fully intact"146. Both churches "wish to be considered Christian by the rest of the Christian world, and they should be". ${ }^{147}$ In a recent article on the early history of the NBC under the leadership of Isaiah, he argued that the church "represents neither a syncretic deviation from orthodoxy nor an oasis of indigenous cultural preservation, but was rather an alternative form of Christianity"148. In his insistence on the Christian factor, he rejected Vilakazi's explanation of the church's silence on Jesus with Zulu cultural values, and argued instead that Isaiah's "thinking about God was born from his exegesis and prophetic experiences, not from the propulsions of Zulu notions of family or seniority"149. That implies, however, that Amos Shembe,

\footnotetext{
143 Op.cit., 3.6-7.23-24.

144 Op.cit., $20-22$.

145 Op.cit., 347.352.

146 Joel Edward Tish ken, Prophecy and Power in Afro-Christian Churches: A Comparative Analysis of the Nazareth Baptist Church and the Église Kimbanguiste, PhD dissertation at the University of Texas, Austin 2002, 278.

147 Ibd.

148 Tishken, Christianity, 449.

149 Op.cit., 454.
} 
who referred to Zulu values when defending his father's position in 1930, was either ignorant of it, or falsified it, maybe to propagate Zulu nationalism. According to Tishken, salvation in Isaiah's theology rested entirely on obedience to God's eternal law, especially with regard to the Sabbath. From this position follows logically "a notion of Godhead with an ascendant Father and a Son less mighty than he"150. Tishken explained the Nв C's silence on Jesus in terms of Subordinationist theology, and argued that Isaiah's position was not unique in this regard, precisely because it is one logical alternative in Christianity. While he rightly emphasized the importance of the Sabbath within the NBC, he remained silent on dancing, the other distinguishing practice that likewise opened the door to paradise, as the most prominent example for the importance of African cultural traditions within the church. In addition, he ignored hymns or testimonies that could move the NBC of Isaiah's times beyond the category of even alternative Christianity.

All the contributions to the theological discourse on the NBC presented here either take an inclusive or exclusive position. If the NBC is included, its representation is made to fit the Christian frame, and embarrassing superstitions are silenced. If the $\mathrm{NBC}$ is excluded, it still cannot be left alone, because the evangelizing Church demands that they be properly educated and their souls be saved. In both cases, epistemic pressure is applied, as Londa expressed clearly, "In the past Christians used a stick to beat us. They said we were pagans and that our followers ought to join real churches. Now they are using a carrot. They say we are just another Christian denomination. In this way they are trying to bring us under their control."151

But is it even possible to represent the NBC and the position of its leader beyond the yardstick of Christianity?

From my social science perspective, the central practice that makes the leaders is the kneeling of the followers. Members of the NBC kneeled in front of Isaiah, and they shouted "You are holy! Amen!", and they continued to do so in front of all the successors. Kneeling also decided the church's succession conflicts in practice, as it communicated the members' choice and acknowledged the new leader in public. Kneeling and other bodily postures are effective in communication, because "to kneel subordination [...] is not simply to state

\footnotetext{
$150 \quad$ Op.cit., 462.

151 Нехнам, Isaiah Shembe, $363-364$.
} 
subordination, but to display it, and how may information concerning the state of a transmitter better be signaled than by displaying that state itself?"152 However, kneeling just communicates the relation between Shembe and his followers, their subordination. Here it pays to heed Vilakazi's warning when he asked "[w]hy is kneeling before the head of a church construed as acts of sacred devotion to a Black Christ, when kneeling and kissing of the Bishop's ring in the Anglican and Catholic churches are not so construed?"153 Regarding the two senses of representation emphasized by Spivak, Shembe is speaking for (vertreten) those who kneel in front of him. ${ }^{154}$ But what does he re-present (darstellen) for them?

The answer has to deal with the twin problem of heterogeneity among the followers, and ambiguity in the presentation of Shembe. On the one hand, Shembe meant different things to different followers, and the re-presentations changed with time. On the other hand, the presentation of Shembe was ambiguous, ranging from the Black Messiah to the Servant of Suffering, in order to attract a wide range of adherents. In the past, I analyzed specific public events, a Sabbath sermon and a speech at university, in which church ministers presented Shembe to others. ${ }^{155}$ Here, I turn to Shembe's iconography.

Pictures of Shembe were objects of material culture shared among church members. Church members also shared "epistemological lenses" to view these images, a covenant of seeing which "stipulates the terms of the gaze that joins viewer and image in a social relation"156. They shared a sacred gaze that allowed "images to open iconically to the reality they portray or even to morph into the very things they represent".157 Through that gaze images of Shembe could represent him in the two senses, they could stand in for him, when the picture healed in his stead, or they could offer true re-presentations, especially when they showed things that could not be seen ordinarily. Stories reproduced the covenant with the images. Stories told about how the photograph of Isaiah printed in the hymnal could heal, how an hospital x-ray showed the healing hand of Johannes, how three stars appearing in a photograph of Amos proved

\footnotetext{
$15^{2}$ Roy Rappaport, Ecology, Meaning, and Religion, Richmond 1979, 199.

153 Vilakazi/Mthethwa/Mpanza, Shembe, 114.

154 Cf. SPIVAK, Subaltern, 70.

155 Cf. EChTLER, Shembe, $256-261$.

156 David Morgan, The Sacred Gaze: Religious Visual Culture in Theory and Practice, Berkeley 2005, 76.105.

157 Op.cit., 259 .
} 
his spiritual unity with Isaiah and Johannes, or how a picture started to switch through the images of Isaiah, Johannes and Amos during a church function. ${ }^{158}$

The first image I want to discuss here shows Jesus, the good shepherd, with a lamb cradled in his right arm, and a shepherd's crook in his left hand. He stands facing the viewer, wears a red gown with a white surplice, has long, slightly wavy brown hair, a full beard, and is white. In front of him, facing him and turned away from the viewer, kneels a man, only about two-thirds of Jesus' size. Skin color and hair suggest that the man is black, he wears a spotted gown which might signify leopard skin. The caption reads, "Khuluma Nkosi inceku yakho iyezwa-Speak, Lord, your servant is listening". The black man is supposed to be Isaiah Shembe, and the scene depicted God making the covenant with him on mount iNhlangakazi. The meaning is straightforward. The image depicts Isaiah as Servant of God, one of his titles. He awaits the command of his Lord, Jesus Christ, and clearly displays his subordinate position. It is the very image of the "safe' and harmless [...] sanitized [...] tame 'native"'159 that Isaiah liked to present when dealing with Mission Christianity, whites, or state power.

However, there is a discrepancy between the image and the stories telling of the making of the covenant. Five of the seven versions I know state explicitly that Isaiah meets Jehovah, and one just speaks of God. ${ }^{160}$ Only the version of Solomon Mdluli speaks of a nameless young man who "was clad in a bright gown and had long hair on his head". He tells Isaiah, "Shembe, I called you to give you my work, for which Jehovah had sent me to do it on earth. I came here on earth to gather the Nazaretha Church and to preach the Gospel all over the world. [...] These people did not join it; rather they decided to kill me. And with my death, this Nazaretha Church [...] came to an end. [...] I commission you with this task, for which I was sent."161 In the story that fits the image, the death of Christ did not lead to salvation, but led to the failure of the Nazarite Gospel, and Shembe is commissioned to take over.

The second image shows a figure with the recognizable face of Isaiah Shembe, wearing a black gown with white surplice, and staff in his left hand. He stands next to a huge ocean wave crashing down on skyscrapers in the

\footnotetext{
158 Cf. Carol Muller, Rituals of Fertility and the Sacrifice of Desire: Nazarite Women's Performance in South Africa, Chicago 1999, 50.245; Hexham/Oosthuizen (eds.), Sun, 24.143.

159 Liz Gunner, Testimonies of Dispossession and Repossession: Writing about the South African Prophet Isaiah Shembe, in: BJRL 73 (1991) 3, 93-103, here 102.

160 Cf. Mpanza, UShembe, 25; Anonymous, Ukuzalwa, 6-7; Hexham/Oosthuizen (eds.), Story, 79-82.

161 Op.cit., 83-84. GUnNER, Testimonies, 98, identifies the young man as Christ.
} 
background. The caption reads, "Lulwandle phinda emumva lapho esakubeka khona sinobudlelwane-Ocean fold back to the place you belong so that we have friendship". According to the corresponding story, Durban was flooded in 1918, and the government could do nothing about it. But there was a white virgin with the surname of Brams, who knew Isaiah Shembe, and suggested he could help, as he had calmed the ocean when baptizing there. And Shembe came, and commanded the sea with his walking stick and the words, "We and our father did not put you here, go back to where you belong."162 And the sea water moved to where it belonged. Heuser argued against Oosthuizen that Isaiah did not usurp the position of Moses, and refers to an article in "Ilanga lase Natal" in 1925 that discredited biblical impostors. Under the headline "Zionist play with danger- they imitate Moses", the article relates how church members almost drowned in a river when their leader failed to part the waves. ${ }^{163}$ In a way, the image and the story told in 2017 answered back directly to the polemic from 1925: Isaiah was like Moses, making a covenant with God, and commanding the waves. In addition, he was present at the time of creation, like in Hymn 71, and, on top of that, actively involved as the Son of God.

The third image is an airbrush painting at the back of a church-owned travelling coach. It shows a steam train crossing a bridge, with a rainbow overhead. Below it is written "Nazareth Baptist Church", and below the number plate "Shembe is the way". "Bhombela, the Pondoland train" is one of the praise names of Isaiah Shembe, relating to his call to iNhlangakazi mountain, when he took this train to avoid the call, and Jehovah stopped it. ${ }^{164}$ "The rainbow (uThingolwenkosazane)" is Vimbeni's name within the church. The image thus re-presents the unity of the spiritual, eternal Shembe. And, in case there might be any doubt, Moodley asked church members, "Shembe is the way, what does it mean to you"? 64 of his 68 respondents replied that it means "Shembe is the only way to heaven and to God". 165 Vimbeni answered, "Shembe is the way in so far as Jesus said, 'I am the way and the truth. Nobody sees my Father but through me because my Father is in me and I in Him.'”166

\footnotetext{
162 Interview with preacher SHENGE (alias), transcript and translation Mduduzi Buthelezi, Durban, 18th January 2017.

163 Cf. Heuser, Soldaten, 118, my translation.

164 Cf. Mpanza, UShembe, 23.

165 Moodley, Shembe, 223.

166 Op.cit., 345 .
} 
What does it mean to be a Nazarite in 2017? You might have read the article about the court's decision, whose title "Court ends god-like Shembe leader's reign" reproduced the epistemic violence directed at the church from its beginnings. ${ }^{167}$ But as a Nazarite you know that the paper is wrong. No earthly court can end the reign of iNkosi uNyazi yeZulu, whom you together with the overwhelming majority acknowledged as the new Lord of the NBC. If the history of the church taught you anything, it is defiance against the legalistic power of the state. The new leader is strong; he is no mere human. Testimonies about his miracles prove that the eternal Shembe resides in him. Just like the founder, he led you on foot to a new holy mountain, iKhenana, Canaan, the land of plenty. Even the Zulu king paid him his respect when he visited the Sabbath service on 14th January 2017.

If you are still going to school, Nazarite, teachers try to force you to cut your "long, natural style" hair, even in the middle of Zululand, and even though the Commission for the Promotion and Protection of the Rights of Cultural, Religious and Linguistic Communities told them to "stay away from children's religious practice"168. The teachers harassed you, they withheld stationary and threatened not to let you take your exams, but you were strong, you "resisted, while others succumbed and cut their hair"169.

You live in post-apartheid South Africa. President Jacob Zuma, who likes to dress traditionally on occasion, in an outfit that looks a lot like the dancing attire of the NBC, built himself a rather exuberant version of a neo-traditional homestead on taxpayers' money. But a Xhosa schoolteacher asked herself what is wrong when she is wearing traditional clothing on Heritage Day only. ${ }^{170}$ She answered with a quote from Steve Biko, anti-apartheid hero,

If by integration you understand a breakthrough into white society by blacks, an assimilation and acceptance of blacks into an already

167 Desiree Erasmus, Court ends god-like Shembe leader's reign, in: African News Agency, 18th October 2016, http://www.iol.co.za/news/crime-courts/court-ends-god-like-shembeleaders-reign-2081235, accessed 23rd February 2017. See also CABRITA, Text, 173-174.

168 Bongani Hans, Shembe Hair: Education Authorities in Trouble with the Law, in: The Mercury, 18th November 2016, http://www.iol.co.za/news/crime-courts/shembe-haireducation-authorities-in-trouble-with-the-law-2091452, accessed 23rd February 2017.

169 Ibd.

170 Атнамвile Masola, Heritage day: What is wrong with this picture? http://thoughtleader.co.za/athambilemasola/2016/og/26/heritage-day-whats-wrong- with-this-picture/, accessed 5th January 2017. 
established set of norms and code of behaviour set up by and maintained by whites, then YES I am against it. I am against the superior-inferior white-black stratification that makes the white a perpetual teacher and the black a perpetual pupil (and a poor one at that). ${ }^{171}$

You know that "not only missionaries [...] treated Western clothing as the outer sign of inner grace", but as a Nazarite, you put on your African attire and start to dance an African dance. ${ }^{172}$ You "dance for him who is praiseworthy"; you are on your way to paradise and you will "enter the gates with dancing"173. As a Nazarite virgin, you "dance with hope" and "shall not be afraid" because you are "perfect"174.

On the way back down from the congregation on the holy mountain you listen to Lucky Dube, the late reggae artist and NBC member. Track five, "Shembe is the way",

No one will undermine my religion. No one will undermine my culture anymore. Cause God sent him from above, to be with the people. Bring them back to what is their own. [...] Oh Shembe thank you for showing us the way. ${ }^{175}$

And you remember how the founder presented his calling as a rupture in the epistemic imbalance that reproduced Western domination over Africa, how he used revelation - the direct contact with Jehovah — to liberate the black pupil from the white teacher. "If you had educated him in your schools, you would have taken pride in him, but that God may demonstrate his wisdom, he sent Shembe, a child, so that he may speak like the wise and learned men."176

Whom does Shembe stand for? You, the Nazarites. What does he re-present to you? I do not know. But for me, your faithful social anthropologist, it seems the only way to resist the epistemic violence of theologically influenced academic discourse is to insist that Shembe is the Black Messiah.

\footnotetext{
171 Steve Biko, I Write What I Like, Oxford 1987, 24.

172 Hilda Kuper, Costume and Identity, in: CSSH 15 (1973), 348-367, here 357.

173 Muller (ed.), Shembe Hymns, 131.139.

174 Loc.cit., 109.

175 LuCKy Dube, Respect, Gallo Record Company, South Africa 2006.

176 Dube, Ushembe, 34 .
} 


\section{Bibliography}

\section{Primary Sources}

Anonymous, Ukuzalwa kuka Shembe, Ebuhleni no date (8 page photocopied typescript).

KaBekhuzulu, Goodwill Zwelithini, speech at Sabbath service, transcribed and translated by Brilliant Mbedu, eKhenana, 14th January 2017.

CELE, Sabbath sermon, transcribed by Sicelo Mpungose and translated by Zakhona Maduna, eBuhleni, 31st January 2009.

Mpanza, Mтнемвеni, UShembe nobuNazaretha: Isaiah Shembe's Summarized Biography, Ebuhleni no date (37 page photocopied typescript, available at the Killie Campbell Library, Durban).

MzWANDILE and BHEKIN Kosi (aliases), interview, transcript by author, Durban, 21st March 2009.

Nonhlanhla (alias), interview, transcribed and translated by Sicelo Mpungose, eBuhleni, 23rd July 2008.

NGсово, MqoqI, speech at the funeral of Vimbeni Shembe, transcribed and translated by Sicelo Mpungose, eBuhleni, 3rd April 2011.

Shembe, Mduduzi, Sabbath sermon, transcribed and translated by Brilliant Mbedu, eKhenana, 21st January 2017.

SHEnge (alias), interview, transcript and translation Mduduzi Buthelezi, Durban, 18 th January 2017.

VILAKAZI, JosEPH J.M., speech at the funeral of Vimbeni Shembe, transcribed and translated by Sicelo Mpungose, Ebuhleni, 3rd April 2011.

\section{News}

Erasmus, Desiree, Court ends god-like Shembe leader's reign, in: African News Agency, 18th October 2016, http://www.iol.co.za/news/crime-courts/court-endsgod-like-shembe-leaders-reign-2081235, accessed 23rd February 2017.

Hans, Bongani, Shembe Hair: Education Authorities in Trouble with the Law, in: The Mercury, 18th November 2016, http://www.iol.co.za/news/crime-courts/ shembe-hair-education-authorities-in-trouble-with-the-law-2091452, accessed 23rd February 2017.

Masola, Aтнамвile, Heritage day: What is wrong with this picture? http:// thoughtleader.co.za/athambilemasola/2016/og/26/heritage-day-whats-wrongwith-this-picture/, accessed 5 th January 2017.

\section{Literature}

Adogame, Afe/Magnus Echtle r/Ulf Vierke, Introduction, in: Afe Adogame/ Magnus Echtler/Ulf Vierke (eds.), Unpacking the New: Critical Perspectives 
on Cultural Syncretization in Africa and Beyond, Beiträge zur Afrikaforschung 36, Berlin 2008, 1-23.

Anderson, Allan, Zion and Pentecost: The Spirituality and Experience of Pentecostal and Zionist/Apostolic Churches in South Africa, Pretoria 2000.

Becken, HANs-Jürgen, The Nazareth Baptist Church of Shembe, in: HANs-Jürgen BECKen (ed.), Our Approach to the Independent Church Movement in South Africa, Mapumulo 1966, 101-114.

В НАв НА, Номі K., The Location of Culture, London 2004.

Biko, Steve, I Write What I Like, Oxford 1987.

Bourdieu, Pierre, Legitimation and structured interest in Weber's sociology of religion, in: Scott LASh/SAm Whimster (eds.), Max Weber, Rationality and Modernity, London 1987, 119-136.

Bourdieu, Pierre, Genesis and Structure of the Religious Field, in: Comparative Social Research 13 (1991), 1-44.

Cabrita, Joel, Politics and Preaching: Chiefly Converts to the Nazaretha Church, Obedient Subjects, and Sermon Performance in South Africa, in: JAfH, 51(2010), 21-40.

Cabrita, Joel, Text and Authority in the South African Nazaretha Church, Cambridge 2014.

Dube, John L., UShembe, Pietermaritzburg 1936, English translation M. Yengwa, London University soAs, Manuscript No. 380082.

Echtler, Magnus, A Real Mass Worship They Will Never Forget: Rituals and Cognition in the Nazareth Baptist Church, South Africa, in: ANGelos CHAniotis ET AL. (eds.), Body, Performance, Agency, and Experience, Ritual Dynamics and the Science of Ritual 2, Wiesbaden 2010, 371-397.

Echtle R, Magnus, Shembe is the Way: The Nazareth Baptist Church in the Religious Field and in Academic Discourse, in: Magnus Echtler/Asonze h UKah (eds.), Bourdieu in Africa: Exploring the Dynamics of Religious Fields, SRA 44, Leiden 2016, 236-266.

Gunner, Elizabeth, Power House, Prison House: An Oral Genre and its Use in Isaiah Shembe's Nazareth Baptist Church, in: JSAS 14 (1988), 204-227.

Gunner, Liz, Testimonies of Dispossession and Repossession: Writing about the South African Prophet Isaiah Shembe, in BJRL 73 (1991) 3, 93-103.

Heuser, Andreas, Shembe, Gandhi und die Soldaten Gottes: Wurzeln der Gewaltfreiheit in Südafrika, Religion and Society in Transition 4, Münster etc. 2003. Heuser, Andreas, Memory Tales: Representations of Shembe in the Cultural Discourse of African Renaissance, in: JRA 35 (2005), 362-387.

Heuser, Andreas, Contested Charisma: Reflections on the Appearance and Disappearance of Female Visionary Power in a South African Independent Church, 
in: Zeitschrift für Globalgeschichte und vergleichende Gesellschaftsforschung 17 (2007) 5/6, 76-94.

Hexham, Irving, Introduction, in: Irving Hexham (ed.) The Scriptures of the amaNazaretha of Ekuphkameni: Selected Writings of the Zulu Prophets Isaiah and Londa Shembe, Calgary 1994, vii-xxii.

Hexham, Irving, Isaiah Shembe, Zulu Religious Leader, in: Religion 27 (1997), 361-373.

Hexham, Irving / G.C. Oosthuizen (eds.), The Story of Isaiah Shembe: History and Traditions Centered on Ekuphakameni and Mount Nhlangakazi, Sacred History and Traditions of the Amanazaretha 1, translated by HANS-JÜRgEN BECKEN, Lewiston 1996.

Hexham, Irving /G.C. Oosthuizen (eds.), The Story of Isaiah Shembe: Early Regional Traditions of the Acts of the Nazarites, Sacred History and Traditions of the Amanazaretha 2, translated by HANS-JÜRGEN BECKEN, Lewiston 1999.

Kuper, HildA, Costume and Identity, in: CSSH 15 (1973), 348-367.

LÉvi-Strauss, Claude, The Sorcerer and His Magic, in: idem, Structural Anthropology, translated by Claire Jacobson/Brooke Grundfest Schoepf, New York 1963, 167-185.

Moodley, Edley Joseph, Shembe, Ancestors, or Christ? A Missiological Inquiry into the Status and Role of Jesus Christ in the Amanazaretha Church, Kwa Zulu Natal, South Africa, PhD Dissertation, Asbury Theological Seminary, Wilmore 2004. Morgan, David, The Sacred Gaze: Religious Visual Culture in Theory and Practice, Berkeley 2005.

Muller, Carol, Rituals of Fertility and the Sacrifice of Desire: Nazarite Women's Performance in South Africa, Chicago 1999.

Muller, Carol (ed.), Shembe Hymns, translated by Bongani Mthethwa, Scottsville 2010.

Oosthuizen, Gerhardus Cornelius, The Theology of a South African Messiah: An Analysis of the Hymnal of the "Church of the Nazarites", OeS 8, Leiden 1967.

Oosthuizen, Gerhardus Cornelius, Post-Christianity in Africa: A Theological and Anthropological Study, London 1968.

Oosthuizen, Gerhardus Cornelius, The Theology of Londa Shembe and the amaNazaretha of EKuphaKameni, in: Irving Hexham (ed.) The Scriptures of the amaNazaretha of Ekuphkameni: Selected Writings of the Zulu Prophets Isaiah and Londa Shembe, Calgary 1994, xxiii-xlix.

PAPIni, Robert, Rise Up and Dance and Praise God, Durban 1992.

PAPIni, Robert, Carl Faye's transcript of Isaiah Shembe's testimony of his early life and calling, in: JRA 29 (1999), 243-284.

Papini, Robert, The Move to Tradition: Dance Uniform History in the Church of Nazareth Baptists, in: African Art 29 (2004) 3, 48-61. 
Papini, Robert/Irving Hexham (eds.), The Catechism of the Nazarites and Related Writings, Sacred history and traditions of the Amanazaretha 4, translated by HANsJürgen Becken/Phyllis Zungu, Lewiston 2002.

RAPPAPORT, RoY, Ecology, Meaning, and Religion, Richmond 1979.

Roberts, Esther, Shembe: The Man and his Works, Johannesburg 1936 (University of the Witwatersrand, MA Thesis).

Sit hole, Nkosinathi, An African Bible for African Readers: J.G. Shembe's Use of the Bible in the Sermon, in: OTE 24 (2011), 208-220.

Sithole, Nkosinathi, Decolonizing the Word: Themba Masinga and his Religious Poetry in Ibandla LamaNazaretha, in: Religion 45 (2015), 191-208.

Sithole, Nkosinathi, Isaiah Shembe's Hymns and the Sacred Dance in Ibandla LamaNazaretha, SRA 45, Leiden 2016.

Spivak, Gayatri Chakravorty, Can the Subaltern Speak?, in: Patrick Williams / Laura Chrisman (eds.), Colonial Discourse and Post-Colonial Theory, New York 1993, 66-111.

Sundkler, Bengt, Bantu Prophets in South Africa, London 1961.

SundKLER, BEngt, Zulu Zion and Some Swazi Zionists, London 1976.

Tishren, Joel Edward, Prophecy and Power in Afro-Christian Churches: A Comparative Analysis of the Nazareth Baptist Church and the Église Kimbanguiste, PhD dissertation at the University of Texas, Austin 2002.

Tishren, Joel Edward, The Nazareth Baptist Church as Subordinationist Christianity, in: AfS 74 (2015) 3, 449-469.

Vilakazi, Absolom/Bongani Mthethwa/Mthembeni Mpanza, Shembe: The Revitalization of African Society, Johannesburg 1986.

Weber, Max, Wirtschaft und Gesellschaft: Grundriss der verstehenden Soziologie, Tübingen 1972.

West, Gerald O., Reading Shembe 'Re-Membering' the Bible: Isaiah Shembe's Instructions on Adultery, in: Neotest. 40 (2006), 157-184. 